\title{
HAK CIPTA SEBAGAI JAMINAN FIDUSIA
}

\section{Rina Puspitasari}

Magister Kenotariatan Fakultas Hukum Universitas Indonesia

Contact: rina.puspitasari.h@gmail.com

Diterima: 12 Januari 2021

Direvisi: -

Disetujui: 28 September 2021

Hak Cipta: (C2018

Halaman: 1-12

\begin{abstract}
This research was conducted to assess the implementation of Article 16 paragraph (3) of Law Number 28 Year 2014 states that copyright can be used as an object of fiduciary guarantee. The the problem statement are: first, could a copyright can be categorized as an asset for the Authors and/or Copyright Holder in accordance with Article 16 paragraph (3) of Law No. 28 of 2014 concerning Copyright? Second, could copyright be determined as an asset for Authors and/or copyright holders which could be guaranteed as fiduciary rights? Third, how is the authority of a Notary in implementing Copyright as a Fiduciary Guarantee? The results of the research show that a copyright guaranteed by fiduciary can be executed for the execution of Article 29 of Law Number 42 of 1999 about Fiduciary the reason is the economic right of the copyright could be secured (it is an intangible object). Besides, related to the Notary, the authority of the Notary to make burden of fiduciary deed has already been mentioned on the Article 5 Section (1) about Fiduciary, thus there is no reason for the Notary to reject for creating deed of fiduciary with copyright as the object.
\end{abstract}

Keywords: Hak Cipta (Copyright), Jaminan Fidusia (Fiduciary Guarantee 


\section{PENDAHULUAN}

Seperti yang kita tahu sebelumnya bahwa tahun 2020 merupakan tahun yang berat bagi seluruh umat manusia di muka bumi ini, karena mewabahnya virus Covid-19 (pandemic Covid-19) di seluruh dunia. Seluruh sektor perekonomian terkena dampak dari pandemi Covid-19 ini, usaha pariwisata, kuliner, industry, bahkan sampai bidang ekonomi kreatif. Semua pihak memindahkan jalur bisnisnya ke ranah digital, dan bukan hal yang baru bahwa pada era sekarang ini perkembangan teknologi dan ekonomi kreatif berkembang dengan sangat pesatnya. Setiap orang dapat memanfaatkan teknologi dengan sangat mudah untuk melakukan suatu atau beberapa usaha guna memenuhi kebutuhan hidupnya. Usaha adalah setiap tindakan atau kegiatan dalam bidang perekonomian yang dilakukan untuk tujuan memperoleh keuntungan dan/ atau laba (Pasal 1 angka 1 Peraturan Menteri Kebudayaan dan Pariwisata RI No PM.87/HK.501/MKP/2010).

Para pelaku usaha di bidang ekonomi kreatif terkena dampak yang cukup signifikan, seperti halnya penyanyi atau musisi atau pelaku pertunjukan, mereka yang biasanya melakukan show-show atau konser-konser, karena pandemic Covid-19 terpaksa membatalkan rencananya show atau konsernya yang sudah direncanakan berbulan-bulan sebelumnya. Begitu pula dengan penyanyi atau musisi yang biasa tampil pada kafe, resto atau pub atau di pesta perkawinan, mereka tidak dapat melakukan pekerjaannya tersebut karena adanya peraturan dari Pemerinta Pusat ataupun Pemerintah Daerah setempat yang memberlakukan sistem Pembatasan sosial berskala Besar (PSBB) di masing-masing wilayahnya.

Selain para pelaku pertunjukan tersebut, begitu pula dengan para Pencipta lagu dan/atau pemegang Hak Cipta, mereka yang merupakan anggota suatu Lembaga Manajemen Kolektif tertentu, yang dimana mandapatkan royaltinya dari pembayaran para pengguna Komersial melalui LMKN, juga mengalami pendapatan royalti yang sangat drastis. Pemberlakukan PSBB berdampak sangat signifikan terhadap pendapatan royalti para Pencipta dan/atau Pemegang Hak Cipta. Dengan adanya PSBB tersebut maka restoran/kafe, pusat perbelanjaan, pusat rekreasi, tempat karaoke keluarga, alat transportasi massa banyak yang tutup atau tidak beroperasi, bahkan adanya larangan konser/show karena guna menghindari adanya kerumunan.

Para Pengguna Komersial lagu dan/atau musik lebih kreatif dalam memikirkan cara agar pelanggan tertarik untuk berkunjung ke tempat usahanya, seperti restoran dan/atau kafe, pusat perbelanjaan, pusat kebugaran, pusat rekreasi, transportasi massal dan lain sebagainya, selain penataan interior yang menarik, biasanya pelaku usaha akan memutarkan lagu/musik atau bahkan menampilkan band (di restoran dan/atau kafe, pusat perbelanjaan, pusat rekreasi dsb) agar pengunjung dapat lebih betah dan nyaman. Hal ini merupakan 
perbuatan yang mempunyai akibat hukum karena lagu dan/atau musik atau karya cipta musisi merupakan suatu hak kekayaan intelektual yang telah dilindungi oleh Undang-Undang No 28 Tahun 2014 tentang Hak Cipta (selanjutnya akan disebut dengan UUHC Tahun 2014).

Menurut UUHC Tahun 2014, pengertian Hak Cipta adalah hak eksklusif Pencipta yang timbul secara otomatis berdasarkan prinsip deklaratif setelah suatu ciptaan diwujudkan dalam bentuk nyata tanpa mengurangi pembatasan sesuai dengan ketentuan peraturan perundangundangan (Pasal 1 ayat (1) UU HC). Sedangkan Direktorat Jenderal Kekayaan Intelektual (DJKI), Kemenkumham RI, mengatakan bahwa:

" Hak Cipta merupakan salah satu bagian dari kekayaan intelektual yang memiliki ruang lingkup objek dilindungi paling luas, karena mencakup ilmu pengetahuan, seni dan sastra (art and literary) yang $d i$ dalamnya mencakup pula program komputer. Perkembangan ekonomi kreatif yang menjadi salah satu andalan Indonesia dan berbagai negara dan berkembang pesatnya teknologi informasi dan komunikasi mengharuskan adanya pembaruan Undang-Undang Hak Cipta, mengingat Hak Cipta menjadi basis terpenting dari ekonomi kreatif nasional. Dengan Undang-Undang Hak Cipta yang memenuhi unsur pelindungan dan pengembangan ekonomi kreatif ini maka diharapkan kontribusi sektor Hak Cipta dan Hak Terkait bagi perekonomian negara dapat lebih optimal".

Lembaga Manajemen Kolektif Nasional (LMKN) adalah Lembaga Bantu Negara non Anggaran Pendapatan dan Belanja Negara (APBN) yang mendapatkan kewenangan atribusi dari UndangUndang Hak Cipta 2014 untuk menarik, menghimpun, dan mendistribusikan royalti serta mengelola kepentingan hak ekonomi pencipta dan pemilik hak terkait di bidang lagu dan/atau music (Pasal 1 angka 7 Peraturan Menteri Hukum dan HAM No. 36 tahun 2018 tentang Tata Cara Permohonan dan Penerbitan Izin Operasional Serta Evaluasi Lembaga Manajemen Kolektif). LMKN diatur secara khusus dalam BAB III Peraturan Menteri Hukum dan Hak Asasi Manusia Republik Indonesia No. 36 tahun 2018 tentang Tata Cara Permohonan dan Penerbitan Izin Operasional Serta Evaluasi Lembaga Manajemen Kolektif.

Setiap Para Pengguna Komersial yang memanfaatkan Hak Cipta dalam bidang lagu dan/atau musik harus menaati ketentuan dalam UUHC Tahun 2014 sebab Para Pengguna Komersial yang sudah memutarkan lagu dan/atau musik di dalam tempat usahanya wajib untuk mendapatkan izin Pencipta dan/atau Pemegang Hak Cipta. Setiap orang yang tanpa izin pencipta atau pemegang Hak Cipta dilarang melakukan penggandaan dan/atau penggunaan secara komersial ciptaan (Pasal 9 ayat (3) UUHC). Selanjutnya, Pemegang Hak Cipta berhak memberikan lisensi kepada pihak lain dalam perjanjian tertulis bagi pihak yang 
ingin menggunakan ciptaannya. Perjanjian lisensi ini akan disertai kewajiban penerima lisensi untuk memberikan royalti. Kemudian Pencipta atau Pemegang Hak Cipta akan memberikan kuasa kepada LMK untuk memungut royalti bagi kepentingan Pencipta, Pemegang Hak Cipta dan Pemilik Hak Terkait.

\section{RUMUSAN MASALAH}

Pertama, apakah Hak Cipta dapat dikategorikan sebagai aset bagi Pemilik dan/atau Pemegang Hak Cipta sesuai dengan Pasal 16 ayat (3) Undang-undang No. 28 Tahun 2014 Tentang Hak Cipta? Kedua, apakah Hak Cipta sebagai Aset bagi Pemilik dan/atau Pemegang Hak Cipta dapat dijaminkan sebagai Hak Fidusia? Ketiga, bagaimanakah wewenang Notaris dalam melaksanakan Hak Cipta sebagai Jaminan Fidusia?

\section{TUJUAN PENELITIAN}

Pertama, penelitian ini bertujuan untuk mengetahui kategori benda atau asset yang dapat dijaminkan, termasuk Hak Cipta sebagai Jaminan Fidusia; Kedua, untuk mengetahui prakteknya Hak Cipta sebagai Jaminan Fidusia di Indonesia; dan ketiga, untuk mengetahui sebatas mana wewenang Notaris dalam melaksanakan ketentuan Hak Cipta sebagai Jaminan Fidusia.

\section{METODOLOGI PENELITIAN}

Penelitian tesis ini menggunakan metode penelitian yuridis normatif yang bersifat kualitatif. Metode ini dilakukan dengan melakukan studi kepustakaan yaitu dengan mengumpulkan data berupa peraturan perundang-undangan terkait, maupun data sekunder berupa literatur, hasil penelitian dan pengkajian. Kajian ini dipahami sebagai kajian kepustakaan, yaitu penelitian terhadap data sekunder.

Oleh Karena Karena tipe penelitian yang digunakan adalah tipe penelitian yuridis normatif, maka pendekatan yang digunakan adalah Pendekatan perundang-undangan dan pendekatan analitis.

\section{HASIL DAN PEMBAHASAN}

Pengolahan dan analisis data pada dasarnya tergantung pada jenis datanya. Untuk penelitian hukum normatif yang menggunakan data sekunder, yang terdiri dari bahan hukum primer, bahan hukum sekunder dan bahan hukum tertier; maka pengolahan datanya tidak bisa dilepas dari berbagai penafsiran yang dikenal dalam ilmu hokum (Amirudin dan Zainal Asikin , 2004, hlm. 166).

Semua data yang diperoleh dari studi pustaka yang didukung data primer dianalisis dengan metode kuantitatif. Burhan Ashsopa menyebutkan bahwa metode kuantitatif dapat digunakan karena tipe penelitian ini adalah penelitian hukum normatif, yang pendekatannya deskriptif teoritis (Burhan Ashsopa, 2000, hlm. 58).

\section{Kategori benda atau asset yang dapat dijaminkan, termasuk Hak Cipta sebagai Jaminan Fidusia}


Hak Cipta adalah hak eksklusif pencipta yang timbul secara otomatis berdasarkan prinsip deklaratif setelah suatu ciptaan diwujudkan dalam bentuk nyata tanpa mengurangi pembatasan sesuai dengan ketentuan peraturan perundangundangan. Pasal 8 UUHC Tahun 2014 menjelaskan bahwa hak ekonomi merupakan hak eksklusif pencipta atau pemegang Hak Cipta untuk mendapatkan manfaat ekonomi atas ciptaan.

Hak Cipta mengandung 2 (dua) esensi hak, yaitu: hak ekonomi (economic rights) dan hak moral (moral rights). Kandungan hak ekonomi meliputi hak untuk mengumumkan (performing rights) dan hak untuk memperbanyak (mechanical rights). Adapun hak moral meliputi hak untuk dicantumkan namanya dalam ciptaan dan hak pencipta untuk melarang orang lain mengubah ciptaannya, termasuk judul ataupun anak judul ciptaan. Keduanya lazim disebut right of paternity dan right of integrity.

Salah satu hak ekonomi (economic rights) yang dimiliki oleh pencipta atau pemegang Hak Cipta ialah hak atas performing rights dengan mendapatkan royalti dari setiap orang atau badan yang menyiarkan, menampilkan, menayangkan, memutarkan komposisi atau karya lagu kepada khalayak luas atau dengan kata lain penggunaan untuk tujuan komersial. Tujuan komersial artinya memperdengarkan kembali lagu dan musik ciptaan seseorang yang dapat memberikan keuntungan bagi pelaku usaha (Para Pengguna Komersial), misalnya pada hotel, diskotik, restoran, kafe, radio dan televise, dan lain sebagainya.

Pasal 9 ayat (2) UUHC Tahun 2014 mengatur bahwa setiap orang yang melaksanakan hak ekonomi sebagaimana dimaksud pada Pasal 9 ayat (1) yaitu pencipta atau pemegang Hak Cipta memiliki hak ekonomi untuk melakukan penerbitan ciptaan, penggandaan ciptaan dalam segala bentuknya, penerjemahan ciptaan, pengadaptasian, pengaransemenan atau pentransformasian ciptaan, pendistribusian ciptaan atau salinannya, pertunjukan ciptaan, pengumuman ciptaan, komunikasi ciptaan, penyewaan ciptaan wajib mendapatkan izin pencipta atau pemegang Hak Cipta. Jadi, setiap orang yang tanpa izin dilarang untuk melakukan penggandaan dan/ atau pengumuman karya cipta secara komersial dan tanpa izin.

DJKI adalah instansi di bawah naungan Kemenkumham RI yang menaungi segala masalah Hak Kekayaan Intelektual (Intellectual Property Right), dalam situsnya juga menyebutkan Ciptaan yang dapat dilindungi antara lain adalah sebagai berikut (Burhan Ashsopa, 2000, hlm. 58):

1. Buku, program komputer, pamflet, perwajahan (layout) karya tulis yang diterbitkan, dan semua hasil karya tulis lain;

2. Ceramah, kuliah, pidato, dan ciptaan lain yang sejenis dengan itu; 
3. Alat peraga yang dibuat untuk kepentingan pendidikan dan ilmu pengetahuan;

4. Lagu atau musik dengan atau tanpa teks;

5. Drama atau drama musikal, tari, koreografi, pewayangan, dan pantomim;

6. Seni rupa dalam segala bentuk seperti seni lukis, gambar, seni ukir, seni kaligrafi, seni pahat, seni patung, kolase, dan seni terapan;

7. Arsitektur;

8. Peta;

9. Seni Batik;

10. Fotografi;

11. Terjemahan, tafsir, saduran, bunga rampai, dan karya lain dari hasil pengalihwujudan.

Dengan masa perlindungan ciptaan adalah sebagai berikut:

1. Perlindungan Hak Cipta: seumur hidup Pencipta +70 Tahun .

2. Program Komputer: 50 tahun Sejak pertama kali dipublikasikan.

3. Pelaku: 50 tahun sejak pertama kali di pertunjukkan.

4. Produser Rekaman: 50 tahun sejak Ciptaan difiksasikan.

5. Lembaga Penyiaran: 20 tahun sejak pertama kali disiarkan.

\section{Praktek Hak Cipta sebagai Jaminan} Fidusia di Indonesia

Menurut Robert C. Sherwood sebagaimana dikutip oleh Ranti Fauza Mayana dalam buku Perlindungan Desain Industri di Indonesia dalam Era Perdagangan Bebas dalam Hak Kekayaan Intelektual (HKI) Memahami Prinsip Dasar, Cakupan, dan Undang-Undang yang Berlaku disebutkan bahwa terdapat 5 teori dasar perlindungan HKI yaitu (Sudaryat dkk, 2010):

\section{Reward Theory}

Memiliki makna yang sangat mendalam, yaitu pengakuan terhadap karya intelektual yang telah dihasilkan oleh penemu/pencipta/pendesain

sehingga ia harus diberikan penghargaan sebagai imbangan atas upaya kreatifnya dalam menemukan/menciptakan karya intelektualnya

2. Recovery Theory

Dinyatakan bahwa penemu/pencipta/pendesain yang telah mengeluarkan waktu, biaya, serta tenaga untuk menghasilkan karya intelektualnya harus memperoleh kembali apa yang telah dikeluarkannya.

\section{Incentive Theory}

Berdasarkan teori ini, insentif perlu diberikan untuk mengupayakan terpacunya kegiatan-kegiatan penelitian yang berguna. 


\section{Risk Theory}

Dalam Risk Theory dinyatakan bahwa karya mengandung resiko. HKI yang merupakan hasil penelitian mengandung resiko yang memungkinkan orang lain yang terlebih dahulu menemukan cara tersebut atau memperbaikinya. Dengan demikian, adalah wajar memberikan bentuk perlindungan hukum terhadap upaya atau kegiatan yang mengandung resiko tersebut.

\section{Economic Growth Stimulus Theory}

Perlindungan atas HKI merupakan alat pembangunan ekonomi. Sebuah Negara yang sistem perlindungan HKI berjalan dengan baik, maka pertumbuhan ekonominya akan baik pula.

Dikaji dari berbagai teori diatas, Indonesia memerlukan Economic Growth Theory, dengan teori ini, memungkinkan sistem HKI yang baik akan menjadi alat pembangunan ekonomi suatu negara. Maka sejatinya hak ekonomi milik Pencipta dapat disejajarkan dengan suatu asset yang dapat dijaminkan oleh pemiliknya untuk mendapatkan pinjaman dari pihak Bank/kreditur lainnya.

Perkembangan Hak Cipta dengan adanya Undang-Undang Nomor 28 Tahun 2014 Tentang Hak Cipta memberikan perlindungan hukum bagi Pencipta, selain itu Hak Cipta juga dapat dijadikan sebagai objek jaminan fidusia, hal ini menunjukan bahwa Hak Cipta sekarang ini sangat bermanfaat bagi Pencipta karena dengan hasil ciptaan dapat digunakan sebagai agunan dalam memperoleh utang. Ketentuan mengenai Hak Cipta dapat dijadikan sebagai jaminan fidusia tertuang dalam Pasal 16 ayat 3 UUHC Tahun 2014. Hal ini tentunya sangat berarti Pencipta dapat mengakses kredit dengan cara menjaminkan karya ciptaanya kedalam jaminan fidusia.

Pasal 16 ayat 3 UUHC Tahun 2014 mempertegas bahwa Pencipta dapat menjaminkan karya ciptaannya melalui jaminan fidusia. Selain hal Pencipta dapat memfidusiakan hasil ciptaannya, hal ini diharapkan Pencipta mampu untuk meningkatkan kualitas suatu ciptaan. Selain itu dengan dikeluarkanya UUHC Tahun 2014 diharapkan mampu untuk meningkatkan kualitas bagi Usaha Mikro Kecil dan Menengah (UMKM), sehingga kesiapan diharapkan Indonesia mampu bersaing di Era Mayarakat Ekonomi Asean terutama dalam bidang ekonomi.

Kegiatan utang-piutang yang sering dilakukan oleh masyarakat sekarang ini, salah satunya adalah menggunakan Lembaga Jaminan Fidusia. Lembaga Jaminan Fidusia dinilai efektif dalam mengatasi laju perkembangan ekonomi. Jaminan fidusia telah digunakan di Indonesia sejak zaman penjajahan Belanda yang semula berasal dari Romawi sebagai salah satu bentuk jaminan yang lahir dari yurisprudensi. Di Negeri asalnya tersebut, selain bentuk jaminan, juga sebagai lembaga titipan. Dalam hukum Romawi lembaga fidusia ini dikenal dengan nama fiducia cum 
creditore contracta (artinya janji kepercayaan yang dibuat oleh kreditor). Pada awalnya benda yang menjadi objek jaminan fidusia dibatasi dengan benda bergerak berwujud dalam bentuk peralatan, akan tetapi dengan kemajuan zaman benda yang menjadi objek jaminan fidusia meliputi benda bergerak tak berwujud ataupun benda bergerak.

Menurut Undang-undang Nomor 42 Tahun 1999 Tentang Jaminan Fidusia (UUJF) bahwa pengertia fidusia adalah pengalihan hak kepemilikan suatu benda atas dasar kepercayaan dengan ketentuan bahwa benda yang hak kepemilikannya dialihkan tersebut tetap dalam penguasaan pemilik benda (Pasal 1 angka 1 UU Jaminan Fidusia). Sedangkan Jaminan Fidusia adalah hak jaminan atas benda bergerak baik yang berwujud maupun yang tidak berwujud dan benda tidak bergerak khususnya bangunan yang tidak dapat dibebani hak tanggungan sebagaimana dimaksud dalam Undang-undang Nomor 4 Tahun 1996 tentang Hak Tanggungan yang tetap berada dalam penguasaan Pemberi Fidusia, sebagai agunan bagi pelunasan utang tertentu, yang memberikan kedudukan yang diutamakan kepada Penerima Fidusia terhadap kreditor lainnya (Pasal 1 Angka 2 UU Jaminan Fidusia).

Perjanjian fidusia adalah perjanjian yang muncul karena adanya perjanjian kredit bank. Apabila nasabah debitur wanprestasi, bank dapat mengambil pelunasan utang dari hasil penjualan barang jaminan fidusia. Dalam praktik ada kecenderungan bahwa objek jaminan fidusia akan dikuasai Bank jika nasabah debitur tidak sanggup melunasi hutang. Dengan demikian kalau terjadi kepailitan dari nasabah debitur, bagaimana status barang jaminan fidusia? Apakah kreditur fidusia diakui sebagai kreditur separatis murni sebagaimana yang dimaksud dalam Pasal 27 ayat (3) UUJF? Hal ini menghendaki kejelasan sehubungan dengan kedudukan preferensi pemegang fidusia.

Kredit yang diberikan oleh bank didasarkan atas kepercayaan sehingga pemberian kredit merupakan pemberian kepercayaan nasabah. Oleh karena itu pemberian kredit oleh bank dimaksudkan sebagai salah satu usaha bank untuk mendapatkan keuntungan, maka bank hanya boleh meneruskan simpanan masyarakat kepada nasabahnya dalam bentu kredit (Djumhana, 2006, 361).

\section{Wewenang Notaris dalam melaksanakan ketentuan Hak Cipta sebagai Jaminan Fidusia}

Penggunaan Hak Cipta sebagai Jaminan Fidusia tidak lepas dari karakteristik objek dari Jaminan Fidusia. Karakteristik benda yang dapat dijaminkan sebagai objek Jaminan Fidusia adalah benda yang mempunyai nilai ekonomis dalam artian suatu saat apabila debitur tidak dapat melunasi utangnya benda itu dapat menutup utang tersebut. Dalam kaitanya dengan Hak Cipta, Hak Cipta memiliki hak moral dan hak ekonomi sehingga dapat dimungkinkan untuk digunakan sebagai Jaminan Fidusia. Hak moral adalah hak yang melekat secara abadi 
pada diri pencipta untuk tetap mencantumkan namanya pada salinan sehubungan dengan pemakaian ciptaannya untuk umum. Hak ekonomi adalah hak eksklusif pencipta atau pemegang Hak Cipta untuk mendapatkan manfaat ekonomi atas ciptaan.

Kenyataannya, menjadikan Hak Cipta sebagai objek Jaminan Fidusia bukan hal yang mudah dilakukan (Elnizar, 2018). Selama ini sangat jarang ditemukan bahkan belum pernah ada upaya menjadikan benda bergerak yang tidak berwujud sebagai objek Jaminan Fidusia.

Dalam praktiknya, para Notaris di Indonesia sulit dalam menilainya Hak Cipta dengan uang, dan hingga saat ini belum ada pedoman penilaian atas nilai ekonomis benda tidak berwujud seperti Hak Cipta. Norma tersebut dibiarkan sebatas menjadi norma dalam undangundang tanpa ada peraturan pelaksana hingga sekarang. Kenyataan belum ada kejelasan mekanisme untuk menjadikan hak cipta sebagai objek Jaminan Fidusia. Padahal, regulasi mengenai jaminan sangat berkaitan dengan upaya pembangunan ekonomi Indonesia.

Pada sektor perbankan cenderung menolak Hak Cipta sebagai Jaminan Fidusia karena persoalan valuasi dalam bentuk uang, karena Bank akan berusaha memberikan kredit agar kredit itu bisa kembali, sedangkan apabila barang atau asset yang dijaminkan adalah berbentuk kekayaan intelektual (Hak Cipta), mereka akan kesulitan cara menilainya barang tersebut. Disamping itu hal lain yang belum jelas adalah cara eksekusi. Apabila kreditnya bermasalah, bagaimana eksekusinya atas Hak Cipta tersebut? Sehinggan pada akhirnya, perbankan di Indonesia tidak bersedia memberikan pembiayaan dengan jaminan Hak Cipta.

Persoalan Hak Cipta sebagai Jaminan Fidusia bukan hal yang mudah. Pertama, harus dipahami bahwa konstruksi Hak Cipta di Indonesia dibagi menjadi hak ekonomi dan hak moral. Hak Cipta dapat menjadi Jaminan Fidusia sebatas pada hak ekonominya. Kedua, hak ekonomi yang bisa dialihkan ini pun membuat Pemegang Hak Cipta tidak selalu si Pencipta.

Misalnya buku menjadi komersial ketika sudah dijual. Saat penulis memberi lisensi penerbitan, yang bisa jadi debitur itu penulis atau penerbit? Akan menjadi lebih kompleks ketika berkaitan dengan Hak Cipta dalam musik. Pencipta musik, produser, artis yang menampilkan pertunjukan musik, dan komposer masing-masing memiliki hak ekonomi untuk suatu wujud karya yang sama. Padahal barangnya satu, yaitu karya rekaman.

Oleh karena itu, perlu ada kejelasan soal siapa yang berhak menjadi debitur dalam Jaminan Fidusia berupa hak cipta. Peran penting notaris dibutuhkan untuk menyusun konstruksi hak apa saja yang diserahkan kepada kreditur sebagai Jaminan Fidusia.

Selain itu diperlukan sistem valuasi yang bisa dipercaya jika masih ingin mempertahankan Hak Cipta sebagai jaminan fidusia. Sistem valuasi ini perlu 
dikelola lembaga khusus untuk menjamin nilai hak yang dibebani fidusia dapat dinikmati pemegang fidusia jika debitur cidera janji. Hal lain yang perlu disediakan adalah pasar untuk menguangkan hak tagih dalam bentuk hak cipta tersebut. Dimana ada satu masa pemegang fidusia sudah malas untuk menagih maka barang yang dijaminkan tersebut dijual oleh si pemegang fidusia, apabila dalam bentuk karya ciptaan maka bagaimana cara menjual karya ciptaan tersebut.

\section{KESIMPULAN}

Hasil penelitian menyimpulkan, pertama, terbukanya peluang untuk Hak Cipta dijaminkan secara fidusia merupakan sebuah hal baru yang perlu dikaji melalui pengamatan hukum. Terlepas dari teori keilmuan hukum yang mengkategorikan Hak Cipta sebagai bagian dari sistem kebendaan yang bersifat immateril karena merupakan cakupan dari hak kekayaan intelektual. Saat ini dalam prakteknya memang menjaminkan secara fidusia terhadap Hak Cipta belum terjadi di Indonesia namun untuk jangka waktu kedepan bukan merupakan suatu hal yang mustahil dalam penerapannya. Penulis melihat Keberadaan Pasal 16 ayat (3) UU Nomor 28 Tahun 2014 tentang Hak Cipta berpotensi menimbulkan problematik hukum dalam praktek kedepan apabila tidak ada regulasi yang benar-benar mengakomodir keberlakuan hak cipta sebagai objek jaminan fidusia. Problematik hukum tersebut berkaitan dengan masalah proses eksekusi atas Hak Cipta yang dijaminkan fidusia manakala debitur selaku pihak Pemberi Fidusia melakukan wanprestasi atau cidera janji. Tentu saja dasar hukum utama yang menjadi pijakan berkaitan dengan Hak Cipta sebagai Objek Jaminan Fidusia tersebut adalah Undang-Undang Nomor 42 Tahun 1999 tentang Jaminan Fidusia sehingga kedepan apabila peluang Hak Cipta dapat dijaminkan fidusia benar-benar terbuka maka permasalahan mengenai tata cara mengeksekusi Hak Cipta dapat diterapkan dengan mengacu aturan utamanya yakni UU Jaminan Fidusia dengan tetap memperhatikan sebagian atau seluruh hak ekonomi atas Hak Cipta yang dijaminkan.

Kedua, kewenangan Notaris untuk membuat akta pembebanan jaminan fidusia atas Hak Cipta maka dalam hal ini notaris memang diberikan kewenangan tersebut sebagaimana ketentuan Pasal 15 ayat (1) UU Nomor 2 Tahun 2014 jo. Pasal 5 ayat (1) UU Nomor 42 Tahun 1999. Meskipun objek yang dijaminkan fidusia berupa hak cipta merupakan hal relatif baru dalam bidang hukum maka menjadi tantangan bagi Notaris, Pelaku Usaha/Bisnis dan Pihak Perbankan/Lembaga Keuangan lain untuk dapat menerapkannya dalam jangka kedepan. Surat Pencatatan Ciptaan bagi ciptaan yang dicatatkan ke Dirjen KI dan/atau Surat Pernyataan Kepemilikan Hak Cipta yang dibuat secara tertulis baik otentik maupun di bawah tangan bagi ciptaan yang tidak dicatatkan dipandang sah saja untuk dapat dijadikan sebagai dokumen pendukung bagi Notaris dalam membuat 
akta pembebanan Jaminan Fidusia atas Hak Cipta. Namun surat pencatatan ciptaan tersebut tidak dapat dikatakan sebagai bukti surat yang sifatnya otentik layaknya sebuah akta. Surat pencatatan ciptaan hanya sebuah surat yang sifatnya bukan akta dan hanya sebagai bukti kepemilikan Hak Cipta yang diberikan kepada Pencipta atas ciptaannya yang telah dicatatkan di Dirjen KI Kementerian Hukum dan Hak Asasi Manusia RI.

Pemberlakuan Hak Cipta sebagai Objek Jaminan Fidusia di Indonesia bukan semudah membalikkan telapak tangan untuk diterapkan meskipun UndangUndang Nomor 28 Tahun 2014 tentang Hak Cipta telah mengakomodir peluang tersebut.

Seandainya jika kedepan konsep penjaminan fidusia atas hak cipta benarbenar diterapkan, maka perlu dilakukan pengaturan lebih lanjut mengenai mekanisme penjaminan fidusia yang berobjekkan hak cipta. Hal ini dilakukan dengan alasan masih banyaknya pihakpihak yang belum memahami bahkan mengetahui terbukanya peluang hak cipta sebagai bagian hak kekayaan intelektual dapat dijaminkan secara fidusia. Selain melakukan penyusunan aturan hukum setingkat dan/atau di bawah Undang-Undang, hal yang tidak kalah penting untuk dilakukan adalah Pemerintah melalui Kementerian Hukum dan Hak Asasi Manusia Republik Indonesia melakukan sosialisasi tentang Hak Kekayaan Intelektual (HKI) dan mengenai pemberlakuan Pasal 16 ayat (3) UU Hak Cipta yang memberikan peluang bagi seiap orang baik Para pelaku Usaha secara pribadi maupun UMKM dan badan usaha lainnya yang bergerak dalam industri kreatif di bidang seni, karya sastra, ilmu pengetahuan dan teknologi untuk dapat menjaminkan hak cipta yang dimilikinya secara fidusia.

Perlunya memberikan pemahaman terhadap Notaris terkait pembuatan akta jaminan fidusia atas hak cipta sebab tentunya dalam akta jaminan akan mengalami penambahan dan/atau perubahan klausul. Sehingga dengan dilaksanakannya sosialisasi tersebut dan dalam rangka peningkatan kualitas bagi para notaris Indonesia tidak ada alasan bagi para Notaris untuk menolak membuatkan akta jaminan fidusia yang objeknya Hak Cipta.

\section{DAFTAR PUSTAKA Buku}

Amirudin dan Zainal Asikin. Pengantar Metode Penelitian Hukum, Jakarta: Rajawali Pers. 2004.

Ashsopa, Burhan. Metode Penelitian Hukum. Jakarta: Rineka Cipta. 2000

Djumhana, Muhamad. Hukum Perbankan di Indonesia, Bandung: PT Citra Aditya Bakti.2006.

Sudrajat, SH, dkk. Hak Kekayaan Intelektual: Memahami Prinsip Dasar, Cakupan, dan Undang-undang yang berlaku. Bandung: Oase Media. 2010.

\section{Internet}

"Pengenalan Hak Cipta". https://dgip.go.id/pengenalan-hak-cipta. 
Diunduh 15 November 2020.

Elnizar, Normand Edwin. "Hak Cipta Sebagai Jaminan Fidusia Terhambat Sistem Valuasi". https://www.hukumonline.com/berita/ baca/lt5bb340c6822c8/hak-ciptasebagai-jaminan-fidusia-terhambatsistem-valuasi?page $=$ all. $\quad(2)$ Oktober 2018). Diakses 30 Oktober 2020.

\section{Peraturan Perundang-undangan}

Indonesia. Undang-undang Tentang Hak Cipta. UU No.: 28 Tahun 2014.

Indonesia. Undang-undang Tentang Jaminan Fidusia. UU No.: 42 Tahun 1999.

Kementerian Kebudayaan dan Pariwisata, Peraturan Menteri Kebudayaan dan Pariwisata RI tentang Tata Cara Pendaftaran Usaha Jasa Makanan dan Minuman. PMKP No PM.87/HK.501/MKP/2010.

Kementerian Hukum dan Hak Asasi Manusia. Peraturan Menteri Hukum dan Hak Asasi Manusia Republik Indonesia tentang Tata Cara Permohonan dan Penerbitan Izin Operasional Serta Evaluasi Lembaga Manajemen Kolektif. PMHHAM No 36 tahun 2018. 